\title{
CURRENT UPDATES ON COVID-19 VACCINES
}

\author{
SHASHI KIRAN MISRA ${ }^{1}$, KAMLA PATHAK ${ }^{2 *}$, DEVENDER PATHAK ${ }^{2}$, RAMAKANT YADAV ${ }^{3}$
}

${ }^{1}$ Department of Pharmacy, University Institute of Pharmacy, CSJMU, Kanpur, India. ${ }^{2}$ Department of Pharmacy, Faculty of Pharmacy, Uttar Pradesh University of Medical Sciences, Saifai, Etawah, Uttar Pradesh, India. ${ }^{3}$ Department of Medical Sciences, Faculty of Medical Sciences, Uttar Pradesh University of Medical Sciences, Saifai, Etawah, Uttar Pradesh, India. Email: kamlapathak5@gmail.com

Received: 10 February 2021, Revised and Accepted: 18 March 2021

ABSTRACT

COVID-19 caused the world to shut down and made us to critically look out at our advanced healthcare systems that are well prepared for heart diseases, cancers, organ transplantation but not for attack of a tiny virus. WHO and other authorized bodies are continuously issuing advisory on preventive measurements, tracking the outbreak and distributing vital medical kits. Besides, scientific community and vaccine experts have developed and started to distribute safe and effective immunization worldwide. Effective deployments of vaccines are reliant on sophisticated technology, scalable production rate and provided funds.The paper outlines several developed and developing immunization vehicles that will hit global market in year 2021. Different platforms including mRNA, DNA, Viral vectors, Synthetic peptides etc. are also conversed here that are globally involved for elimination of SARS-CoV-2, a causative virus of COVID-19.

Keywords: COVID-19, Vaccine, Viral vector, SARS-CoV-2, Synthetic peptide.

(C) 2021 The Authors. Published by Innovare Academic Sciences Pvt Ltd. This is an open access article under the CC BY license (http://creativecommons.org/ licenses/by/4.0/) DOI: http://dx.doi.org/10.22159/ajpcr.2021v14i5.41061. Journal homepage: https://innovareacademics.in/journals/index.php/ajpcr

\section{INTRODUCTION}

The first human coronavirus was reported in the year 1960. Until now seven different genera of coronaviruses are known. All are infectious and causes mild respiratory symptoms to mortal outcomes. In December 2019, SARS-CoV-2 emerged that causes COVID-19, a severe respiratory illness worldwide. The scientific and medical communities are developing effective weapons to defeat this threat. Development of vaccine requires approximately 10-15 years for research and clinical testing (phase study), but year 2020 let the scientists to embark on a fight against COVID-19 by formulating safe and effective vaccines within months. Worldwide eminent researchers are aggressively engaged round the clock for the development of effective inoculation. Preclinical and clinical trials including phase study are restraining steps for the formulation of vaccine to avoid severe adverse effects [1]. Urgent need of effective COVID-19 vaccine insisted combination of phase 1 and 2 in clinical trials. Authorized bodies allow emergency use of developed vaccine to lessen worldwide morbidity and mortality rates. In this pandemic situation, when corona has been continuously engulfing millions of lives, worldwide countries are co-operating each other to fight against COVID-19 through sharing research and scientific information [2]. Several active international organizations such as World Health Organization (WHO), Bill and Melinda Gates foundation (BMGF), Gavi Alliance, Coalition for Epidemic Preparation Innovations (CEPI), and Accelerating COVID-19 Therapeutic Interventions and Vaccines (ACTIV) are conjoining for effectively elimination of virus, ensuring for sufficient funding and fair vaccine distribution [3]. According to reports gathered on Jan 2021, researchers are involved in analyzing 64 vaccines as clinical trials on human beings [4]. Approximately 85 vaccines are under preclinical testing for their active ingredients in animals whereas 20 vaccines are in final stage of phase study. Development of vaccine involves various steps such as exploratory phase, preclinical phase, phase 1 , phase 2 , phase 3 , approval, and post-marketing surveillance [5]. Fig. 1 illustrates step by step preclinical and clinical trials conducted both on animals and humans for evaluation of safety and efficacy.

The global endeavor to develop a potent and safe COVID-19 vaccine is now commencement with fertile results. Till date, few vaccines are been approved around worldwide for deployment (Table 1).

\section{DIVERSE PLATFORMS FOR THE DEVELOPMENT OF COVID-19 VACCINES}

Coronavirus, causative agent of epidemic COVID-19, is positivesensed, single stranded RNA virus containing helical nucleocapsid. It belongs to family Coronaviridae with four genera, that is, alpha, beta, delta, and gamma. Genera beta-coronavirus is accountable for causing severe acute respiratory syndrome, that is, SARS-CoV-2 [6]. Positive stranded SARS-CoV-2 has four structural proteins, that is, nucleocapsid $(\mathrm{N})$ protein, spike $(\mathrm{S})$ protein, envelop $(\mathrm{E})$ protein, and matrix $(\mathrm{M})$ protein [7]. The S protein is heavily glycosylated and decorated on viral surface that directly bind to the host Angiotensin Converting Enzyme 2 (ACE2) receptor which facilitates virus entry into target cells [8].

Globally, first infected case was reported in December 2019 in China through transmission from bats to human [9]. Afterward almost all countries of world suffer with this fatal virus with typical clinical manifestations such as dyspnea, cough, fever, myalgia, loss in taste, fatigue, and sore throat [10].Population that represent more severe symptoms such as shortness of breath, pneumonia, continuous pain in chest, and bluish lips need immediate medical attention and should be hospitalized [11]. Elevated level of creatinine protein, lactate dehydrogenase, prothrombin time, and reduced albumin is noted down in pathological reports of the sufferer. Mostly geriatric, immune-compromised, hypertensive, and diabetics are victims of virulent corona virus [12]. Literatures stated that patients with high levels of troponin 1 (beyond $13.75 \mathrm{ng} / \mathrm{L}$ ) and aspartate aminotransferase (up to 28U/L) are more likely to develop undesirable outcomes [13]. Current updates on spreading of COVID-19 augmented transmission chain through human-to-human. Direct/indirect contact and dissemination of respiratory droplets from infected person in crowded premises mediate SARS-CoV-2 transmission [14]. In this context, the WHO has been provided basic preventive guidelines related to maintenance of personal hygiene (frequent hand wash with soap, and minimum touch of face), use of medical mask, proper disposal of used tissue and mask and maintain $2 \mathrm{~m}$ social distancing to avoid contact with other person [15]. Moreover, a COVID-19 diagnostic kit is also arranged in clinical testing laboratories. RT-PCR (Reverse Transcriptase Polymerase Chain Reaction) along with chest X-ray, lung ultrasound CT scan, etc., is employed for identification of corona infection. Increased mortality was reported with cardiac and diabetic patients [16]. 
Table 1: List of vaccines developed by eminent developers

\begin{tabular}{|c|c|c|c|c|c|}
\hline Vaccine nature & Name & Country of origin & Developer & Approved by & Dose and storage \\
\hline $\begin{array}{l}\text { mRNA-based (95\% efficacy, } \\
\text { muscle injection) }\end{array}$ & $\begin{array}{l}\text { BNT162b2/Comirnaty/ } \\
\text { Tozinameron }\end{array}$ & $\begin{array}{l}\text { Multinational } \\
\text { (New York and } \\
\text { German) }\end{array}$ & $\begin{array}{l}\text { Pfizer, BioNTech, } \\
\text { Fosun }\end{array}$ & $\begin{array}{l}\text { UK, US, EU, Saudi, } \\
\text { Singapur, Oman }\end{array}$ & $\begin{array}{l}2 \text { dose/ } 3 \text { weeks apart } \\
\text { Freezer storage }\left(-94^{\circ} \mathrm{F}\right)\end{array}$ \\
\hline $\begin{array}{l}\text { mRNA-based ( } 94.5 \% \\
\text { efficacy, muscle injection) }\end{array}$ & mRNA-1273 & Bostan, US & $\begin{array}{l}\text { Moderna, BARDA, } \\
\text { NIAID }\end{array}$ & US and Canada & $\begin{array}{l}2 \text { dose } / 4 \text { weeks apart } 30 \\
\text { days in refrigerator and } 6 \\
\text { months at }-4^{\circ} \mathrm{F}\end{array}$ \\
\hline $\begin{array}{l}\text { Replication deficient } \\
\text { viral vector vaccine ( } 90 \% \\
\text { efficacy, muscle injection) }\end{array}$ & $\begin{array}{l}\text { AZD1222 (Covishield } \\
\text { in India) }\end{array}$ & $\begin{array}{l}\text { The University } \\
\text { of Oxford, The } \\
\text { Jenner Institute }\end{array}$ & $\begin{array}{l}\text { The University of } \\
\text { oxford, AstraZeneca, } \\
\text { Serum Institute of } \\
\text { India }\end{array}$ & Britain & $\begin{array}{l}2 \text { dose } 4 \text { weeks apart Stable } \\
\text { in refrigerator for } 6 \text { months }\end{array}$ \\
\hline $\begin{array}{l}\text { Inactivated Vaccine } \\
\text { unknown efficacy }\end{array}$ & Yet to be named & China & $\begin{array}{l}\text { Wuhan institute of } \\
\text { biological products, } \\
\text { Sinopharm }\end{array}$ & $\begin{array}{l}\text { Limited to } \\
\text { emergency used in } \\
\text { China and United } \\
\text { Arab Emirates }\end{array}$ & Unclear \\
\hline $\begin{array}{l}\text { Inactivated vaccine }(0 \% \\
\text { efficacy) }\end{array}$ & $\begin{array}{l}\text { CoronaVac (formerly } \\
\text { PiCoVacc) }\end{array}$ & China & Sinovac & Limited use China & $\begin{array}{l}2 \text { dose } 2 \text { weeks apart Stable } \\
\text { in refrigeration }\end{array}$ \\
\hline $\begin{array}{l}\text { Non replicating viral vector } \\
\text { ( } 91.4 \% \text { efficacy, Muscle } \\
\text { injection) }\end{array}$ & $\begin{array}{l}\text { Sputnik V (formerly } \\
\text { Gam-COVID-Vac) }\end{array}$ & Russia & $\begin{array}{l}\text { Gamaleya research } \\
\text { institute }\end{array}$ & Russia & $\begin{array}{l}2 \text { dose } / 3 \text { weeks apart } \\
\text { Freezer storage }\end{array}$ \\
\hline $\begin{array}{l}\text { Peptide vaccines (Unknown } \\
\text { efficacy, muscle vaccine) }\end{array}$ & EpiVacCorona & CanSino Biologics & & Russia & $\begin{array}{l}2 \text { dose } 3 \text { weeks apart Stable } \\
\text { for } 2 \text { years in refrigerator }\end{array}$ \\
\hline $\begin{array}{l}\text { Inactivated corona vaccine } \\
\text { (Unknown efficacy) }\end{array}$ & $\begin{array}{l}\text { Covaxin (BBV152 A, B, } \\
\text { and C) }\end{array}$ & $\begin{array}{l}\text { Bharat Biotech, } \\
\text { India }\end{array}$ & $\begin{array}{l}\text { ICMR and National } \\
\text { Institute of Virology }\end{array}$ & India & $\begin{array}{l}2 \text { dose } 3 \text { weeks apart Stable } \\
\text { in room temperature for } \\
\text { a week }\end{array}$ \\
\hline
\end{tabular}

\begin{tabular}{|c|c|c|c|c|c|c|}
\hline $\begin{array}{l}\text { Exploratory phase } \\
\begin{array}{|l}\begin{array}{l}\text { It involves basic } \\
\text { laboratory bench } \\
\text { research and } \\
\text { computational to }\end{array} \\
\text { modeling to } \\
\text { identify natural or } \\
\text { synthetic antigens } \\
\text { as vaccine } \\
\text { candidate }\end{array}\end{array}$ & $\begin{array}{l}\text { clinical phase } \\
\text { It involves cell- } \\
\text { culture, tissue- } \\
\text { culture systems } \\
\text { and trials on an } \\
\text { animal model to } \\
\text { assess the safety of } \\
\text { the candidate } \\
\text { vaccine and its } \\
\text { immunogenicity }\end{array}$ & $\begin{array}{l}\text { Phase 1 } \\
\text { The vaccine is } \\
\text { given to a small } \\
\text { number of } \\
\text { healthy and } \\
\text { immunocompro } \\
\text { mised } \\
\text { individuals to } \\
\text { primarily test } \\
\text { for safety, } \\
\text { appropriate } \\
\text { dose and to } \\
\text { check for } \\
\text { immune } \\
\text { response, as a } \\
\text { secondary } \\
\text { effect. }\end{array}$ & $\begin{array}{l}\text { The vaccine is } \\
\text { given to } \\
\text { hundreds of } \\
\text { people split in to } \\
\text { different groups } \\
\text { by demographics } \\
\text { to evaluate } \\
\text { appropriate } \\
\text { dosage, interval } \\
\text { between doses } \\
\text { and immune } \\
\text { response, as a } \\
\text { secondary effect }\end{array}$ & \begin{tabular}{l}
\multicolumn{1}{c}{ Phase 3} \\
This is a large-scale \\
trial where the \\
vaccine is given to \\
thousands of \\
people to evaluate \\
efficacy
\end{tabular} & $\begin{array}{l}\text { Review and } \\
\text { approval } \\
\text { Food and Drug } \\
\text { Administration } \\
\text { (FDA) of the USA, } \\
\text { or European } \\
\text { Medicines } \\
\text { Agency in EU, } \\
\text { must review the } \\
\text { results from } \\
\text { clinical trials and } \\
\text { decide if the } \\
\text { vaccine is fit to } \\
\text { be approved }\end{array}$ & 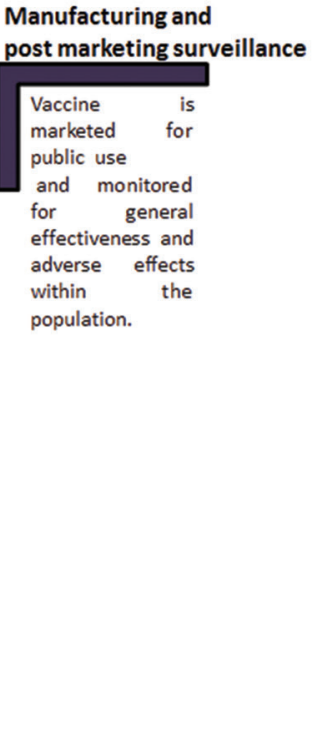 \\
\hline
\end{tabular}

Fig. 1: Schematic illustration of development process of a vaccine

Researchers immensely analyzed core structure of highly contagious corona virus (SARS-CoV-2) for designing infallible treatment/vaccine through targeting its surface protein. As surface of corona virus is composed of trimeric glycoprotein (S protein) that has two subunits, that is, S1 (controls receptor binding site) and S2 (facilitates membrane fusion). This "S" protein is diverse in nature that endures momentous conformational change during pre-fusion and post- fusion with host [17]. Recent researches emphasize that viral vaccine expressing over $\mathrm{N}$ protein causes induction of $\mathrm{T}$ cells dependent immunity hence open new arena for fabrication of anti-SARS-Co-V-2 candidates [18]. A safe and effective COVID-19 vaccine would protect the population in either of two ways. First as direct protection where high risk people are to be immunized to avert the disease and second is indirect prevention through vaccinate in touch people to lessen COVID-19 transmission rate.

Researchers and vaccine experts have designed several vaccines (Fig. 2) through targeting $\mathrm{S}$ protein present on surface that gets bind to the host cells. Various vaccines development platforms reliant on mRNA, DNA, inactivated corona virus, synthetic multiple, and multitope peptides and non-replicating viral vectors are acknowledged by researchers.

\section{Inactivated vaccines}

Inactivated vaccines are widely administered for the treatment of Flu, Polio, and Rabies since 1880s. Purified inactivated virus candidate is 

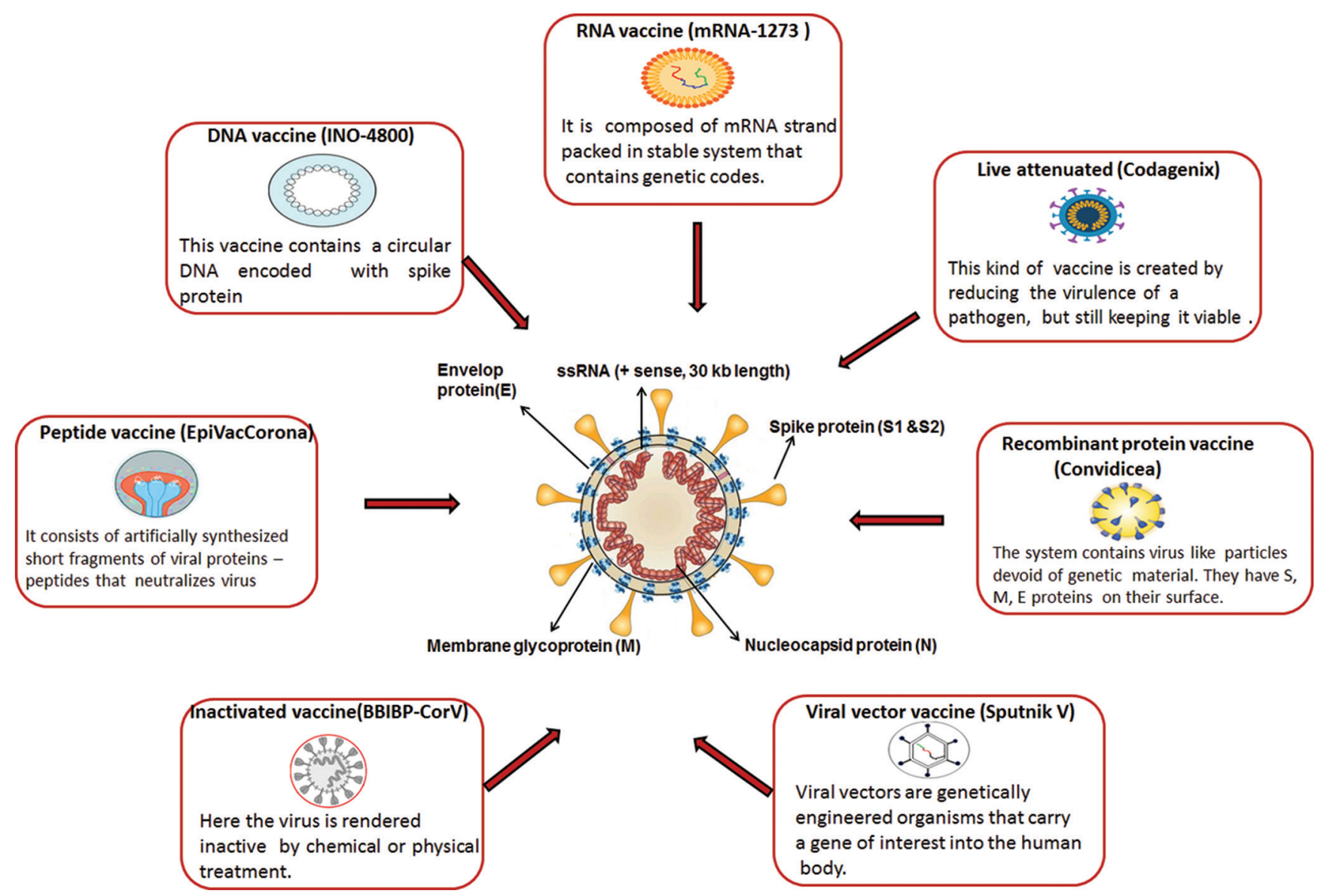

Fig. 2: Typical structure of SARS-CoV-2 and divers platforms for developed vaccines

been explored for the vaccine development and mitigation of influenza. These preparations are quite stable and easy to produce in limited resources [19]. Here, the virus is rendered inactive by chemical or physical treatment. After administering the vaccine, the immune system encounters the all sum virus. The system defenses the host cells through detecting viral spike protein (S protein) and nucleoprotein. Collaborated efforts for development of two inactivated vaccines (Table 2) are intimated by Wuhan Institute of Biological Products, Beijing Institute of Biological Products and Sinopharm against SARS-CoV-2 [20]. In this context, Zhang et al., 2020, have investigated tolerability, safety, and immunogenicity of developed inactivated vaccine, that is, CoronaVac, Sinovac Life Science, China. Two doses of the Corona-Vacvaccines ( 0 and 28 days) were well tolerated in mice, rates and non-human primates. However, administered doses $(3 \mu \mathrm{g}$ and $6 \mu \mathrm{g}$ ) were moderately immunogenic in adult human of age group between 18 and 59 years. The adverse effects by both doses were almost similar and suggested dose-independent safety concerns. Thus, CoronaVacvaccine, $3 \mu \mathrm{g}$ was channelized for production and global distribution. Inactivated vaccine CoronaVac produced mild fever and pain at site compare to other RNA vaccine, DNA vaccine, and viral vector vaccine [21]. Valneva's inactivated vaccine VLA2001 against SARSCov-2 is currently in phase $1 / 2$. This vaccine contains inactivated whole corona virus particle with high density of $\mathrm{S}$ protein in amalgamation with alum, two adjuvants and CpG 1018, a component of HEPLISAV-B vaccine. Valneva plans to get initial regulatory approval for distribution of VLA2021 vaccine across worldwide in the fourth quarter of 2021 as it believes to complete phase 3 study at that time. An agreement between Valneva and UK authority has been announced in September 2020 for distribution of 60 million doses of VLA2001 in the year 2021 and additional 130 million doses to the UK government in the duration of 2022-2025. Moreover, the company has a positive discussion with European commission for the supply VLA2001 vaccines (approximately 60 million doses) if the development goes successful.
Indian vaccine "COVAXIN (BBV152)" is developed by Bharat Biotech with joint collaboration of Indian Council of Medical Research and National Institute of Virology. The vaccine is composed of inactivated whole virion (SARS-CoV-2) with Algel and Algel-IMDG as adjuvants. The report claims no serious adverse effects after immunization to 375 participants. The inoculum is planned to administer in two doses, 4-6 weeks apart and can be stored at cold temperature $\left(2^{\circ} \mathrm{C}-8^{\circ} \mathrm{C}\right)$, hence ideal for national immunization programs [22].

Another inactivated whole virus vaccine is been introduced by Wuhan Institute of Virology, China. Xia et al. investigated safety and immunogenicity of intramuscular administered developed vaccine. Submitted interim report of phase 1 and phase 2 trails demonstrated immunogenicity with low rate of adverse reactions such as site pain and fever. Further, phase 3 study is ongoing by Chinese clinical trial agency (ChiCTR2000031809) to evaluate efficacy and long-term adverse effect if any [23].

\section{DNA vaccines}

These vaccines are third generation vaccines, generally composed of circular piece of bacterial DNA or genetically engineered plasmids that produce unambiguous antigens (template) from a pathogen. Immune response is activated when pathogen's protein are identified through DNA template [24].

Among several technologies of vaccine development, DNA vaccines are promising candidates as it has ability to produce both humoral and cellular immunity. Further, their production, scalability, stability, and storage are feasible [25]. On January 4, 2021, INOVIO and Advaccine Biopharmaceuticals Suzhou Co. declared exclusive right to develop and commercialize INO-4800, a DNA based vaccine in China, Hong Kong, Taiwan and Macao. Recombinant DNA technology is used to develop 
Table 2: Status of vaccine candidates under development

\begin{tabular}{|c|c|c|c|c|}
\hline Vaccine nature & Name of vaccine & Sponsor/developer & Institution & Trial phase \\
\hline Recombinant epivacvaccine & Convidicea or Ad5-nCoV & CanSino Biologics & Tongji Hospital, Wuhan, china & Phase 3 \\
\hline Non-replicating viral vector & JNJ-78436735 & Johnson and Johnson & Johnson and Johnson & Phase 3 \\
\hline Nanoparticle vaccine & NVX-CoV2373 & Novavax & Novavax & Phase 3 \\
\hline DNA vaccine & INO-4800 & INOVIO pharmaceuticals & $\begin{array}{l}\text { Center for Pharmaceutical } \\
\text { research, Kansas City, Philadelphia }\end{array}$ & Phase $2 / 3$ \\
\hline mRNA- based vaccine & $\mathrm{CVnCoV}$ & CureVac & CureVac & Phase $2 / 3$ \\
\hline Plant based adjuvant & VIR- 7831 & Medicago, GSK, Dynavax & Medicago & Phase $2 / 3$ \\
\hline mRNA-based vaccine & BNT162 & Pfizer, BioNTech & Europe, North America, China & Phase $1 / 2 / 3$ \\
\hline $\begin{array}{l}\text { rVSV (Recombinant vesicular } \\
\text { stomatitis virus) vaccine }\end{array}$ & IIBR-100 & $\begin{array}{l}\text { Israel institute for biological } \\
\text { research }\end{array}$ & $\begin{array}{l}\text { Hadassah Medical Center, Sheba } \\
\text { Medical Center }\end{array}$ & Phase $1 / 2$ \\
\hline Conjugate vaccine & Soberana $1 \& 2$ & Finlay institute of vaccine & Finlay institute of vaccine, & Phase $1 / 2$ \\
\hline Inactivated vaccine & VLA2001 & $\begin{array}{l}\text { Valneva, National Institute for } \\
\text { Health Research (NIHR) }\end{array}$ & $\begin{array}{l}\text { Multiple National Institute for } \\
\text { Health Research sites }\end{array}$ & Phase $1 / 2$ \\
\hline SF9 cell vaccine & Yet to be named & $\begin{array}{l}\text { West China hospital Sichuan } \\
\text { University }\end{array}$ & $\begin{array}{l}\text { West China hospital Sichuan } \\
\text { University }\end{array}$ & Phase $1 / 2$ \\
\hline DNA vaccine & AG0301-COVID19 & AnGes, Inc.Japan & $\begin{array}{l}\text { Japan agency for medical research } \\
\text { and development }\end{array}$ & Phase $1 / 2$ \\
\hline Self- amplifying RNA vaccine & LNP-nCoVsaRNA & Imperial college London & Imperial college London & Phase1/2 \\
\hline Protein subunit vaccine & Yet to be named & Sanofi, GSK & Various sites & Phase $1 / 2$ \\
\hline Self-replicating RNA vaccine & $\begin{array}{l}\text { ARCT- } 021 \text { or Lunar } \\
\text { covid }\end{array}$ & $\begin{array}{l}\text { Arcturus Therapeutics and Duke- } \\
\text { NUS Medical school }\end{array}$ & $\begin{array}{l}\text { Duke-NUS Medical school, } \\
\text { Singapore }\end{array}$ & Phase $1 / 2$ \\
\hline Inactivated vaccine & Yet to be named & $\begin{array}{l}\text { Chinese Academy of Medical } \\
\text { science }\end{array}$ & $\begin{array}{l}\text { West China Second University } \\
\text { Hospital \& Yunnan Center For } \\
\text { Disease Control And Prevention }\end{array}$ & Phase $1 / 2$ \\
\hline Adenovirus-based vaccine & AdCLD-CoV19 & Cellid, LG Chem & Korea university Guro Hospital & Phase $1 / 2$ \\
\hline RNA vaccine & HDT-301 (HGCO19) & $\begin{array}{l}\text { HDT Bio Corp, University of } \\
\text { Washington }\end{array}$ & $\begin{array}{l}\text { HDT Bio Corp, University of } \\
\text { Washington }\end{array}$ & Phase $1 / 2$ \\
\hline Live attenuated (Intranasal) & COVI-VAC & Codagenix & Serum Institute of India & Phase 1 \\
\hline DNA plasmid vaccine & CORVax12 & OncoSec & $\begin{array}{l}\text { Providence Portland medical } \\
\text { center }\end{array}$ & Phase 1 \\
\hline $\begin{array}{l}\text { Modified vaccine virus Ankara } \\
\text { vector (MVA) }\end{array}$ & MVA-SARS-2-S & $\begin{array}{l}\text { German center for infection } \\
\text { research, Philipps University } \\
\text { Marburg medical center }\end{array}$ & $\begin{array}{l}\text { University medical center } \\
\text { Hamburg-Eppendorf }\end{array}$ & Phase 1 \\
\hline Multipeptide vaccine & pVAC & University hospital Tuebingen & University hospital Tuebingen & Phase 1 \\
\hline $\begin{array}{l}\text { Monovalent recombinant } \\
\text { protein vaccine }\end{array}$ & COVAX-19 & Vaxine Pvt. Ltd & Royal Adelaide hospital & Phase 1 \\
\hline $\begin{array}{l}\text { Bifidobacteria monovalent oral } \\
\text { vaccine }\end{array}$ & BacTRL-Spike & Symvivo & Symvivocorporation & Phase 1 \\
\hline Replicating viral vector & $\begin{array}{l}\text { DelNS1-2019-nCoV- } \\
\text { RBD-OPT1 }\end{array}$ & $\begin{array}{l}\text { BeizingWantaibiological } \\
\text { pharmacy, Xiamen University }\end{array}$ & $\begin{array}{l}\text { Jiangsu provincial centre for } \\
\text { disease control }\end{array}$ & Phase 1 \\
\hline Adenovirus based vaccine & GRAd-COV2 & ReiThera, Leukocare & $\begin{array}{l}\text { Lazzarospallanzani, national } \\
\text { institute for infectious disease }\end{array}$ & Phase 1 \\
\hline Protein subunit vaccine & UQ-CSL V451 & CSL & The University of Queensland & Phase 1 \\
\hline Protein subunit & SCB-2019 & GSK, Sanofi, Dynavax, CEPI & Linear Clinical Research, Australia & Phase 1 \\
\hline Multitope peptide vaccine & UB-612 & COVAXX & United Biomedical Inc. & Phase 1 \\
\hline $\begin{array}{l}\text { Vesicular stomatitis virus } \\
\text { vaccine (recombinant) }\end{array}$ & V590 & Merck \& Co., IAVI & Merck \& Co., IAVI & Phase 1 \\
\hline $\begin{array}{l}\text { Adenovirus type } 5 \text { vector } \\
\text { (Recombinant) }\end{array}$ & VXA-CoV2-1 & Vaxart & Vaxart & Phase 1 \\
\hline Measles vector vaccine & V591 & $\begin{array}{l}\text { University of Pittsburgh's Center } \\
\text { for vaccine research }\end{array}$ & $\begin{array}{l}\text { University of Pittsburgh, Themis } \\
\text { Biosciences }\end{array}$ & Phase 1 \\
\hline
\end{tabular}

(Data gathered from reference literature "COVID-19 treatment and vaccine tracker" (https://covid-19tracker.milkeninstitute.org, and https://www.who.int/ publications/m/item/draft-landscape-of-covid-19-candidate-vaccines)

viral vaccines that includes encoded antigen DNA for stimulation of immune responses into host cells [26]. Another DNA based plasmid vaccine ZyCov-D is been developed by Zydus Cadila, Ahmedabad, India, currently arrives on phase 3 clinical trial. After administration, DNA sequences in inoculum would match with the SARS-CoV-2 virus, hence mediating development of antibodies against virus. Phase $1 / 2$ clinical trials claim immunogenic, safe, effective, and well-tolerated responses collected from 1000 volunteers. Successfully developed DNA vaccine ZyCoV-D exhibits improved stability, requires lower cold chain and ideal for remote areas. Genexine GX-19 DNA vaccine, currently on Phase $1 / 2$, found to be safe and effective after intramuscular administration in healthy volunteers [27]. South Korean Ministry of Food and Drug Safety has approved Phase 2 clinical trial for effectiveness of GX-19 DNA vaccine. Pharmajet ${ }^{\circledR}$, the maker of GX-19 vaccine announced that Stratis ${ }^{\circledR}$ needle free injection technology will be applied for administration of delivery of GX-19 DNA vaccine against corona virus eradication program. Precise and consistent delivery from the novel needle free technology system will not only facilitate direct reach of inoculum into the host cells but also are safe, fast and easy to use. Moreover, the technology eliminates injection injury, reuse of needle and cross-contamination hence less waste disposal. An international consortium is developed including International Vaccine Institute, GenNBio, Pohang University of science and technology, Binex and Korea advanced institute for science and technology for successful development and analysis of GX-19 vaccines. 


\section{RNA vaccines}

RNA vaccines are composed of mRNA strand that contains genetic codes for a disease specific antigen. mRNA vaccines are favorable inoculum compare to conventional technologies due to its high potency, rapid development, scalability, and cost-effective parameters[28]. Once the system is injected, the coded mRNA serves as template for the host cells that trigger immune system [29]. Moderna, an American based company has developed mRNA-1273 vaccine. As the vaccine is injected, the immune cells starts to target spike "S" protein adorned in corona virus. On September 2020, Moderna Inc. announced second interim analysis of phase 1 study that its vaccine candidate was well tolerated in two doses (25 $\mu \mathrm{g}$ and $100 \mu \mathrm{g}$ ) given in 28 days apart to 40 healthy adult volunteers in two age cohorts (age 56-70 and 71+). Clinical trial study pursued by National institute of Allergy and Infectious Diseases suggested better use of this vaccine to the elderly rather than younger ones [30,31].

Another mRNA vaccine (BNT162B2) introduced by Pfizer (US) and BioNTech (Germany) has enabled to target full length spike S protein. The system is encapsulated in lipid nanoparticles that has potential to enter into host cells, enhances cellular uptake through endocytosis. On November 2020, Phase 3 first interim efficacy analysis of BNT162B2 vaccine was conducted against SARS-CoV-2 participants that suggested potential for prevention of COVID-19. Both Pfizer and BioNTech are jointly working to collecting safety and efficacy data related to second dose of vaccine for the submission to FDA to get further potential emergency use authorization. HDT 301 (repRNA-CoV2S), an Alpha-virus derived self-replicating mRNA vaccine is formulated with lipid inorganic nanoparticles for the enhancement of vaccine release, stability and immunogenicity. Research outcomes from UW medicines and HDT Bio displayed production of antiSARS-CoV-2 S proteins on single immunization into mice and primates. The vaccine potentially neutralizes coronavirus and induces production of IgG antibody isotypes related to helper T cells in the lungs and spleen within 2 weeks of administration. Applied novel nanoparticle approach in this vaccine enables easy in vivo delivery of inoculum after bare mixing that induces desired immune response and provides stability at room temperature for one week. The development of self-replicating mRNA vaccine is easy to formulate, stable, and need not 2 times immunization as in conventional nucleic acid vaccines [32]

ARCT-021 (LUNAR-COV-19), a self-replicating mRNA vaccine designed by Arcturus Therapeutics Holdings Inc. San Deigo, Califorina. The company has received FDA approval for Phase 2 clinical trial. Phase 1/2 study provides sufficient data on well tolerability (in younger of age and older) and both cellular/humoral immunogenicity after administration of single dose $(7.5 \mu \mathrm{g})$. Dose-dependent immunoglobulin $\mathrm{G}$ encoded anti-spike proteins, increased $\mathrm{T}$ cells reactivity, and amplified receptor binding domain are observed through 43 days.

\section{Viral vector vaccines}

Here, immunogens are used to induce pathogen-specific antibodies and immune response. It includes killed, attenuated pathogens, or recombinant pathogens [33]. As these vaccines are prepared through carrier virus (an adeno virus or pox virus) and contain usually $\mathrm{S}$ gene/ protein for competing SARS-CoV-2. After administration in the host, the system induces innate immunity [34].

Sputnik V vaccine is first registered inoculating candidate against COVID-19. This vaccine is different from conventional as they do not contain antigen rather induce body's cells to produce the same. There is a modified virus vector that gets activated after interacting with spike proteins of SARS-CoV-2 and delivers genetic codes for antigen. Virus vector lacks genes responsible for reproduction and making its copies in body cells. It is used to deliver genetic material from another virus that is targeted for vaccination. A genetic code of $\mathrm{S}$ protein from SARS-CoV-2 virus is inserted into two different viral vectors that develop immunity against delivered $\mathrm{S}$ proteins after prime and boost immunization. Gamaleya center of Russia used unique and novel technology using two adenovirus vectors (Ad 26 and Ad 5) that boosts immunity after 21 days.
Oxford University and AstraZeneca, a pharmaceutical company both are engage in developing Covishield vaccine. Its Indian partner "Serum institute" Pune, is enduring for production of viral vector vaccine as brand name AZD1222. This contains weakened, genetically modified, non-replicating strains of SARS-CoV-2 and adenovirus (causative of common cold). The vaccination course consists of two doses (each $0.5 \mathrm{ml}$ ) and should be administered within 4-6 weeks apart. The interim study notified production of plentiful dosedependent anti-spike S Protein immunoglobulin G (Oxford University press release). From the interim analysis, AZD1222 is found $70.4 \%$ efficacious against prevention of COVID-19 with no prominent adverse effects. UK medicine and health-care products regulatory agency has authorized distribution of AZD1222 to the above 18 years individuals. The company has started vaccine weekly trial on United Kingdom participant regardless symptoms [35]. Moreover, AstraZeneca is involved for sufficient production and distribution of approximately 1 million doses of vaccine in the UK with the support of National Health Service, England. The company continuously seeks emergency use approval of AZD1222 from the WHO and tries to make ease of availability in low and middle income provinces at no profit base.

\section{Live attenuated vaccines}

This kind of vaccine is composed of live coronavirus whose virulence is been lessened under laboratory conditions. The system allows less virulent virus to replicate in host cells and produce mild pathogenicity if any. This kind of approach has been successfully demonstrated for the combat of viral infections including smallpox and poliomyelitis [36]. However, geriatrics and diseased patients are not suitable for this kind of vaccination [37]. The Serum Institute of India has allied with US pharmaceutical company "Codagenix" for the development of live attenuated COVID vaccine "Covi-Vac." Intranasal Covi-Vac has completed its preclinical studies and currently in phase 1 . The administration of vaccine does not necessitate skilled person hence appropriate for mass immunization operation. The production of Codagenix vaccine can be scalable due to ease of cell culture and sufficient doses can be formulated to meet worldwide needs. The vaccine was found to be safe and protective on single dose administered in gold standard animal model. However, due to its nature (live attenuated), this vaccine cannot be suitable approach for elderly individuals. Interestingly, the vaccine is designed to develop immunity against all kinds of proteins present on SARS-CoV-2 virus which would elicit vigorous response with long term cellular and humoral immunization [38].

\section{Peptide vaccines}

The approach displays unique features, that is, selectivity and specificity toward the SARS-CoV-2. The peptide based vaccine candidate implies identification of both epitopes, that is, host cells and capsid of virus, counteract host-pathogen connection and induces specific adaptive immunity. This strategy depicts comparatively lesser risks associated with autoimmune response and hypersensitivity due to lack of antigenic elements [39]. Development of peptide vaccines are exclusive of microbial contents, water soluble, stable under simple storage conditions, scalable, and cost effective due to involvement of solid phase peptide technology [40].

EpiVacCorona, a peptide vaccine is developed by Russian Institute "CanSino Biologics, Vektor State Research Center of Virology and Biotechnlogy." The system contains fragments extracted from virus and synthetic peptides that form active antigens in body [39]. EpiVacCorona vaccine stimulates body to produce immunogenic responses by releasing antibodies into host's blood and lymph. The vaccine does not persuade reactogenic responses and is considered for high safety. EpiVacCorona vaccine provokes an immunogenic response against SARS-CoV-2 and maintains future immunity. Russian authorities' claim its effectiveness and prepare for mass immunization in 2021. At present, the vaccine appears in phase 3 including clinical trials (NCT04527575) on adults and pregnant ones as it does not exhibited embryotoxic activity. 
Another, pVAC, a DNA plasmid vaccine of the University hospital Tuebingen, is categorized in dendrimers and cyclopeptides. It is designed to stimulate humoral immunity through intramuscular injection hence neutralizes antibodies. The antigenic multipeptides, present in vaccine, are supposed to be position on the surface of muscle cells that are taken up by antigen presenting cells and mediate the process major histocompatibility complex Class II pathway. Similarly, the UB-612 (COVAXX) of United Biomedical, New York is designed for activation of multiple epitopes and stimulation of both cellular and humoral immunity against SARS-CoV-2 virus. The vaccine is totally synthetic with no biohazardous factor and targeted for the Receptor Binding Domain (RBD) of S protein. The preliminary studies based on clinical aspects, demonstrated that COVAXX will produce high immunogenicity against live virus. In addition, the data suggested generation of more than 1,000,000 anti-S1-RBD titers when measured through ELISA. Reputed worldwide organizations such as the World Health Organization, Gavi, Coalition for Epidemic Preparedness Innovations, and the Vaccine Alliance are seeking measures for sufficient production and delivery of more than 100 million doses in first quarter of 2021. In the arena, COVAXX (Table 2) is trying to establish scalable, low cost vaccine production platform among other developed vaccines candidates.

\section{Recombinant protein vaccine}

This immunization approach includes recombinant proteins encrypted by DNA that supports expression of genes and mutant protein thus eliminates post-vaccination adverse responses [41].

The development of recombinant protein vaccine includes various versions of spike "S" proteins as antigen component [42]

"Convidicea" or "Ad5-nCoV" of CanSino Biologics (China) is the first recombinant protein containing anti SARS-CoV-2 vaccine candidate. Adenovirus based this strategy is currently in phase 3 (Table 2). Novel recombinant strains including replication-defective adenovirus and pneumococcal protein antigens are genetically engineered to target spike protein adorned on SARS-CoV-2 coronavirus. Russian Health Ministry has permitted massive international phase 3 clinical trial (NCT04526990) organized conjointly by CanSino biologics and Petrovax company.

Apart from above quoted conventional approaches, researchers are designing some unconventional strategies for the effective abolition of SARS-CoV-2. In this context, Aivita Biomedical Inc. has formulated autologous dendritic cells "AV-COVID-19" encoded with corona virus antigens. This novel formulation is derived of patients monocytes amalgamated with SARS-CoV-2 antigens incubated dendritic cells [43]. At present, the formulation undergoes phase I/II clinical trial for the evaluation of efficacy and safety in volunteers (NCT04386252). Another, Symvivo Corporation designed bacTRL-Spike vaccine containing live Bifidobacterium and synthetic plasmid DNA to combat COVID-19. In this series, researchers of Nanjing University are engaged to find out binding potential of plant micro RNA (MIR2911) with SARS-CoV-2 mRNA. The outcomes revealed inhibition of coronavirus replication through blocking of protein translation. The formulation is also facing phase I clinical study (ChiCTR2000031432) in China for its tolerance and safety in patients [44].

There are few issues on developed vaccines that create question marks for complete and successful abolition of corona. The probability of rapid disappearance of developed antibody, chances of reinfection, antibodydependent enhancement (ADE), clearance of antigen-antibody complex through another mode, and safety for all age group population are to be resolved out [45]. A study on experimental SARS-CoV-2 stated that reinfection to a vaccinated individual may be more complicated and fatal compare to non-vaccinated person. The developed effective COVID-19 vaccine need to address such issues to control current pandemic, its reoccurrence, and future epidemics [46]. Moreover, most of the developed vaccines does not faced clinical trial on elderly, immunocompromised and comorbidities persons so their effectiveness without serious side effects are also unanswered [47].

\section{CONCLUSION}

Numerous academic institutions and companies of worldwide have developed and evaluated several vaccines after extremely compressed clinical trial agendas. Several developers such as Pfizer and BioNTech, Moderna, AstraZenaca, and Bharat Biotech are ready with their esteemed products for the management of pandemic COVID-19. India itself is now supplying Covishield and Covaxin inoculums under grant assistance to its neighboring countries, that is, Bangladesh, Bhutan, Myanmar, Nepal, Maldives and Seycelles from January 20, 2021. Sundry pharmaceutical technologies reliant on genetics, nanoengineering, and biotechnology are integrated for successful development of these anti-SARS-CoV-2 inoculums. Taking account on conditions of more vulnerable community including immunocompromised, geriatrics, and comorbidities patients the safety and efficacy of vaccine are yet to be monitored. Moreover, unforeseen outcomes of immunization in the varied demographic regions, different races, variant age groups and diseased conditions are to be under surveillance. Thus, post-marketing surveillance (phase IV study) becomes more important as it will provide real observance of efficacy and associated adverse effects once population get immunized.

\section{ACKNOWLEDGMENT}

We gratefully acknowledge the facilities provided from University Institute of Pharmacy, CSJMU Kanpur for generously granting all working facilities and extending their cooperation for designing the manuscript. Our sincere thanks are for Faculty of Pharmacy and Faculty of Medical Sciences, Uttar Pradesh University of Medical Sciences, Saifai, Etawah for their generous assistance to compile present article.

\section{AUTHOR'S CONTRIBUTION}

Dr. R. K. Yadav proposed the current title and conceptualized the article. Dr. Devender Pathak critically reviewed the whole content. Dr. Kamla Pathak supervised the collected details and data. Dr. Shashi Kiran Misra envisaged literatures and drafted the manuscript.

\section{CONFLICT OF INTEREST}

No.

\section{AUTHORS FUNDING}

None.

\section{REFERENCES}

1. Sempowski GD, Saunders KO, Acharya P, Wiehe KJ, Haynes BF. Pandemic preparedness: Developing vaccines and therapeutic antibodies for COVID-19. Cell 2020;181:1458-63.

2. Zhang JJ, Dong X, Cao YY, Yuan YD, Yang YB, Yan YQ, et al. Clinical characteristics of 140 patients infected with SARS-CoV-2 in Wuhan, China. Allergy 2020;75:1730-41.

3. Corey L, Mascola JR, Fauci AS, Collins FS. A strategic approach to COVID-19 vaccine R\&D. Science 2020;368:948-50.

4. Le TT, Cramer JP, Chen R, Mayhew S. Evolution of the COVID-19 vaccine development landscape. Nat Rev Drug Discov 2020;19:667-8.

5. Dai L, Zheng T, Xu K, Han Y, Xu L, Huang E, et al. A universal design of betacoronavirus vaccines against COVID-19, MERS, and SARS. Cell 2020;182:722-33.

6. Zhang J, Zeng H, Gu J, Li H, Zheng L, Zou Q. Progress and prospects on vaccine development against SARS-CoV-2. Vaccines (Basel) 2020;8:153.

7. Walls A, Park Y, Tortorici M, Wall A, McGuire AT, Veesler D. Structure, function and antigenicity of the SARS-CoV-2 spike glycoprotein. Cell 2020;181(2):281-92.

8. To KK, Tsang OT, Leung WS, Tam AR, Wu TC, Lung DC, et al. Temporal profiles of viral load in posterior oropharyngeal saliva samples and serum antibody responses during infection by SARS-CoV-2: An observational cohort study. Lancet Infect Dis 2020;20:565-74.

9. Letko M, Marzi A, Munster V. Functional assessment of cell entry and receptor usage for SARS-CoV-2 and other lineage B betacoronaviruses. Nat Microbiol 2020;5:562-9.

10. Yuksel A, Karadogan D, Gurkan CG, Akyil FT, Toreyin ZN, et al. 
Unclear issues regarding COVID-19. Eurasian J Med 2020;52:191-6.

11. Centers for Disease Control and Prevention. Coronavirus Disease 2019 (COVID-19): Symptoms. Available from: https://www.cdc.gov/ coronavirus/2019-ncov/symptoms.html. [Last accessed on 2020 Mar 14].

12. Bogoch II, Watts A, Thomas-Bachli A, Huber C, Kraemer MU, Khan K. Potential for global spread of a novel coronavirus from China. J Travel Med 2020;27:taaa011

13. Toraih EA, Elshazli RM, Hussein MH, Elgaml A, Amin M, ElMowafy M, et al. Association of cardiac biomarkers and comorbidities with increased mortality, severity, and cardiac injury in COVID-19 patients: A meta-regression and decision tree analysis. J Med Virol 2020;92:2473-88

14. WHO Coronavirus Disease (COVID-19): How is it Transmitted? Available from: https://www.who.int/news-room/q-a-detail/ coronavirus-disease-covid-19-how-is-it-transmitted. [Last accessed on 2020 Dec 11]

15. World Health Organization. Rational Use of Personal Protective Equipment for Coronavirus Disease 2019 (COVID-19). Available from: https://www.apps.who.int/iris/bitstream/handle/10665/331215/ WHO-2019-nCov-IPCPPE use-2020.1-eng.pdf. [Last accessed on 2020 Mar 14].

16. Vashist SK. In vitro diagnostic assays for COVID-19: Recent advances and emerging trends. Diagnostics (Basel) 2020;10:202.

17. Sharpe HR, Gilbride C, Allen E, Belij-Rammerstorfer S, Bissett C, Ewer K, et al. The early landscape of coronavirus disease 2019 vaccine development in the UK and rest of the world. Immunology 2020;160:223-32.

18. Wang N, Shang J, Jiang S, Du L. Subunit vaccines against emerging pathogenic human coronaviruses. Front Microbiol 2020;11:298.

19. Roper RL, Rehm KE. SARS vaccines: Where are we? Expert Rev Vaccines 2009;8:887-98

20. Sinopharm Says Second COVID Vaccine Found to Be Safe; 2020. Available from: http://www.sinopharm-says- $2^{\text {nd }}-$ covid-vaccine-foundto-be-safe-in-testing. [Last accessed on $2020 \mathrm{Jul} 10]$.

21. Bar-Zeev N, Kochhar S. Expecting the unexpected with COVID-19 vaccines. Lancet Infect Dis 2021;21:150-1.

22. Wang $\mathrm{H}$, Zhang Y, Huang B. Development of an inactivated vaccine candidate, BBIBP-CorV, with potent protection against SARS-CoV-2. Cell 2020;182:713-21.

23. Xia S, Duan K, Zhang Y, Zhao D, Zhang H, Xie Z, et al. Effect of an inactivated vaccine against SARS-CoV-2 on safety and immunogenicity outcomes: Interim analysis of 2 randomized clinical trials. JAMA 2020;324:951-60.

24. Zeng F, Chow KY, Hon CC, Law KM, Yip CW, Chan KH, et al. Characterization of humoral responses in mice immunized with plasmid DNAs encoding SARS-CoV spike gene fragments, Biochem Biophys Res Commun 2004;315:1134-9.

25. Silveira MM, Moreira GM, Mendonça M. DNA vaccines against COVID-19: Perspectives and challenges. Life Sci 2021;267:118919.

26. Nascimento IP, Leite LC. Recombinant vaccines and the development of new vaccine strategies. Braz J Med Biol Res 2012;45:1102-11.

27. Seo YB, Suh YS, Ryu JI, Jhang H, Oh H, Koo BS, et al. Soluble Spike DNA Vaccine Provides Long-term Protective Immunity against SARCoV-2 in Mice and Nonhuman Primates. New York: BioRxiv; 2020.

28. Dong Y, Dai T, Wei Y, Zhang L, Zheng M, Zhou F. A systematic review of SARS-CoV-2 vaccine candidates. Signal Transduct Target Ther
2020;5:237

29. Armbruster N, Jasny E, Petsch B. Advances in RNA vaccines for preventive indications: A case study of a vaccine against rabies. Vaccines (Basel) 2019; 7:132.

30. Jackson LA, Anderson EJ, Rouphael NG, Roberts PC, Makhene M, Coler RN, et al. An mRNA vaccine against SARS-CoV-2 - preliminary report. N Engl J Med 2020;383:1920-31.

31. Pfizer Press Release. Pfizer and BioNTech Choose Lead mRNA Vaccine Candidate against COVID-19 and Commence Pivotal Phase 2/3 Global Study. Available from: https:/www.pfizer.com/news/pressrelease/press-release-detail/pfizer-and-biontech-choose-lead-mrnavaccine-candidate-0. [Last accessed on $2020 \mathrm{Jul} 27$ ].

32. Erasmus JH, Khandhar AP, Megan A, Walls AC, Hemann EA, Murapa P, et al. An Alphavirus-derived replicon RNA vaccine induces SARS-CoV-2 neutralizing antibody and $\mathrm{T}$ cell responses in mice and nonhuman primates. Sci Transl Med 2020;12:eabc9396

33. Lu B, Huang Y, Huang L, Li B, Zheng Z, Chen Z, et al. Effect of mucosal and systemic immunization with virus-like particles of severe acute respiratory syndrome coronavirus in mice. Immunology 2010;130:254-61.

34. Afrough B, Dowall S, Hewson R. Emerging viruses and current strategies for vaccine intervention. Clin Exp Immunol 2019;196:157-66.

35. Lipstich M, Dean NE. Understanding COVID-19 vaccine efficacy. Science 2020;370:763-5.

36. Minor PD. Live attenuated vaccines: Historical successes and current challenges. Virology 2015;479-480:379-92.

37. Amanat F, Krammer F. SARS-CoV-2 vaccines: Status report. Immunity 2020;52:583-9.

38. Sharma O, Sultan AA, Ding H, Triggle CR. A review of the progress and challenges of developing a vaccine for COVID-19. Front Immunol 2020;11:585354

39. Li W, Joshi MD, Singhania S, Ramsey KH, Murthy AK. Peptide vaccine: Progress and challenges. Vaccines (Basel) 2014;2:515-36.

40. Skwarczynski M, Toth I. Peptide-based synthetic vaccines. Chem Sci 2016;7:842-54

41. Tripathi NK, Shrivastava A. Recent developments in recombinant protein-based dengue vaccines. Front Immunol 2018;9:1919.

42. Pollet J, Chen WH, Strych U. Recombinant protein vaccines, a proven approach against coronavirus pandemics. Adv Drug Deliv Rev 2021;170:71-82.

43. Li YD, Chi WY, Su JH, Ferrall L, Hung CF, Wu TC. Coronavirus vaccine development: From SARS and MERS to COVID-19. J Biomed Sci 2020;27:104

44. Zhou LK, Zhou Z, Jiang XM, Fu Z, Xiao G, Zhang CY, et al. Absorbed plant MIR2911 in honeysuckle decoction inhibits SARS-CoV-2 replication and accelerates the negative conversion of infected patients. Cell Discov 2020;6:54.

45. Wang J, Zand MS. The potential for antibody-dependent enhancement of SARS-CoV-2 infection: Translational implications for vaccine development. J Clin Transl Sci 2020;5:1-4

46. Jiang S. Don't rush to deploy COVID-19 vaccines and drugs without sufficient safety guarantees. Nature 2020;579:321.

47. Rodriguez-Morales AJ, Cardona-Ospina JA, Gutierrez-Ocampo E, Villamizar-Pena R, Holguin-Rivera Y, Escalera-Antezana JP, et al. Clinical, laboratory and imaging features of COVID-19: A systematic review and meta-analysis. Travel Med Infect Dis 2020;34:101623. 